\title{
Frequency of Adherence Genes cna, fnbA and fnbB in Staphylococcus aureus Isolates from Traditional Cheese
}

\author{
Bahareh Charmifar (MSc) \\ Department of Microbiology, Islamic \\ Azad University, Urmia Branch, \\ Urmia, Iran \\ Saman Mahdavi (PhD) \\ Department of Microbiology, Islamic \\ Azad University, Maragheh Branch, \\ Maragheh, Iran \\ Corresponding author: Saman \\ Mahdavi \\ Email: S.mahdavi@iau-maragheh.ac.ir \\ Tel: +989144150454 \\ Address: Department of \\ Microbiology, Islamic Azad \\ University, Maragheh Branch, \\ Maragheh, Iran
}

Received : 9 Jan 2017

Revised: 10 Mar 2017

Accepted: 15 Mar 2017

\section{ABSTRACT}

Background and Objectives: Several virulence factors are involved in the pathogenesis of Staphylococcus aureus. Surface proteins such as collagen binding proteins ( $\mathrm{Cna}$ ) and fibronectin-binding proteins (FnBP) are important factors in adhesion and invasion of $S$. aureus. The aim of this study was to evaluate the frequency of adherence genes cna, fnbA and fnbB S. aureus isolates from traditional cheese.

Methods: All 22 isolates tested were identified as $S$. aureus. The isolates were tested for the presence of adherence genes $c n a, f n b A$ and $f n b B$ using specific primers in polymerase chain reaction assay.

Results: Six isolates (27.27\%) were positive for the can gene. 0f the 22 isolates studied, one isolate was positive for fnbA and one was positive for the fnbB. Co-presence of the genes examined was not observed in any of the isolates.

Conclusion: The results indicate the weak biofilm formation ability of the $S$. aureus isolates from traditional cheese.

Keywords: Staphylococcus aureus, Biofilm, Genes, Cheese.

This paper should be cited as: Charmifar B, Mahdavi S[Frequency of Adherence Genes cna, fnbA and fnbB in Staphylococcus aureus Isolates from Traditional Cheese ]. mljgoums. 2017; 11(5):11-15 


\section{INTRODUCTION}

Milk and dairy products have an important role in the transmission of spoilage microorganisms and pathogens to consumers (1). Staphylococcus aureus is one of the most important pathogens that can contaminate milk and dairy products, and cause infection in humans. On the other hand, these bacteria can play an important role in the development of chronic mastitis through formation of biofilm (1). Virulence of these bacteria is mediated primarily by various virulence factors such as surface adhesion molecules. According to in vitro studies, adhesion of $S$. aureus to epithelial cells and mammary gland is of great importance for the development of mastitis (2). Adhesion to epithelial cells or extracellular matrix proteins is also effective for blocking outward flow of bacteria in milking (3). S. aureus contains specific adhesion factors that can be attached to a variety of host proteins, especially in the extracellular matrix (4). The adhesion of bacteria is mediated by a family of proteins known as microbial surface components recognizing adhesive matrix molecules. Proteins such as collagen-binding protein (Cna) and fibronectin-binding protein (FnBP) can covalently bind to bacterial cell wall peptidoglycan. Studies have shown that FnBP is essential for the invasion of eukaryotic cells (5). It has been shown that Cna, FnbA and FnbB are significantly important in development of various pathological conditions such as keratitis (6), osteomyelitis, septic arthritis (7) and medical device-related infections (8). Staphylococcus is one of the main pathogens that are involved in the infections associated with implants (injection or implant prosthetics) (9). Studies have also shown that FnBPs on the surface of $S$. aureus are required for adhesion and invasion of bovine mammary cells (10). Some evidence suggests that some $S$. aureus adherence proteins be associated with certain invasive infections (9). Therefore, we aimed to evaluate the frequency of adherence genes $c n a, f n b A$ and $f n b B$ in $S$. aureus isolates from traditional cheese.

\section{MATERIAL AND METHODS}

Twenty-two coagulase-positive $S$. aureus strains were isolated from traditional cheese produced in the city of Maragheh, Iran. The bacteria were cultured in Brain Heart Infusion agar (Merck Co., Germany). One $\mathrm{ml}$ of bacterial suspension was centrifuged at $5000 \mathrm{~g}$ for 5 minutes, and supernatant was discarded. Then, $1 \mathrm{~mL}$ of lysis buffer containing $1 \mathrm{M}$ Tris ( $\mathrm{pH}=7.5$ ), $5 \mathrm{M}$ sodium chloride, 0.5 M EDTA and $2 \% \mathrm{C}-\mathrm{TAB}$ was added to the sediment, and the mixture was placed in bain-marie at 85 ${ }^{\circ} \mathrm{C}$ for 30 minutes. The vials containing the lysed cells were centrifuged at $12000 \mathrm{~g}$ for 5 minutes, and supernatant was transferred to new vials, and then mixed with same volume of chloroform and isoamyl alcohol (ratio 24:1) and shaken gently. After formation of two liquid phases, surface layer was removed from the vials and transferred to another tube. After adding $0.5 \mathrm{ml}$ of RNAase, the tube was placed in bain-marie for 30 minutes at $37^{\circ} \mathrm{C}$. After 30 minutes, content of the vials was mixed with equal volume of isopropanol and then placed at $-20{ }^{\circ} \mathrm{C}$ for 15 minutes. After centrifugation at $12000 \mathrm{~g}$, DNA sedimented was dried at room temperature. Finally, DNA was dissolved in $50 \mathrm{ml}$ of double distilled water (11).

Polymerase chain reaction (PCR) was performed using a $25 \mu \mathrm{l}$ solution prepared from $12.5 \mathrm{ml}$ master mix containing $0.4 \mu \mathrm{M}$ of specific primers (Table 1) and $1 \mu \mathrm{l}$ of DNA extracted $(50 \mathrm{ng})$. PCR was performed starting with predenaturation at $94{ }^{\circ} \mathrm{C}$ for 4 minutes, 32 cycles of denaturation at $94{ }^{\circ} \mathrm{C}$ for 1 minute, annealing at $55{ }^{\circ} \mathrm{C}$ for 1 minute, extension at $72{ }^{\circ} \mathrm{C}$ for 1 minute and final extension at $72{ }^{\circ} \mathrm{C}$ for 10 minutes. PCR product was electrophoresed on $1.5 \%$ agarose gel and observed using gel doc. DNA from $S$. aureus PTCC1112 was used as positive controland double distilled water was used as negative control. Presence of a 275-bp band related to thermonuclease gene confirmed detection of $S$. aureus.

Amplification of the cna gene was carried out using specific primers starting with predenaturation at $94{ }^{\circ} \mathrm{C}$ for $5 \mathrm{~min}, 35$ cycles of denaturation at $94{ }^{\circ} \mathrm{C}$ for 30 seconds, annealing at $52{ }^{\circ} \mathrm{C}$ for 30 seconds, extension at $72{ }^{\circ} \mathrm{C}$ for 30 seconds and final extension at 72 ${ }^{\circ} \mathrm{C}$ for 10 minutes (14). PCR product was electrophoresed on $1 \%$ agarose gel and imaged using gel doc. Detection of a 201 bp band confirmed the presence of the cna gene. Amplification of the $f n b A$ and $f n b B$ genes was carried out starting with predenaturation at $94^{\circ} \mathrm{C}$ for 5 minutes, 35 cycles of denaturation 
at $94{ }^{\circ} \mathrm{C}$ for 1 minute, annealing at $55^{\circ} \mathrm{C}$ for 50 seconds, extension at $72{ }^{\circ} \mathrm{C}$ for 1 minute and final extension at $72{ }^{\circ} \mathrm{C}$ for 5 minutes (15). PCR product was electrophoresed on $1 \%$ agarose gel and imaged with gel doc. Detection of $191 \mathrm{bp}$ and $201 \mathrm{bp}$ bands confirmed the presence of the $f n b A$ and $f n b B$ genes, respectively.

Table 1- Sequence of specific primers used for each gene and PCR product size

\begin{tabular}{|c|c|c|c|}
\hline Reference & Production size(bp) & Sequence & Gene \\
\hline 12 & 275 & 5'-GCGATTGATGGTGATACGGTT-3' & nuc \\
\hline & & 5'-AGCCAAGCCTTGACGAACTAAAGC & \\
\hline 13 & 192 & $\begin{array}{c}\text { 5'-AAAGCGTTGCCTAGTGGAGA-3' } \\
\text { 5'-AGTGCCTTCCCAAACCTTTT-3' }\end{array}$ & cna \\
\hline 13 & 191 & $\begin{array}{l}\text { 5'-GATACAAACCCAGGTGGTGG-3' } \\
\text { 5'-TGTGCTTGACCATGCTCTTC-3' }\end{array}$ & $f(n b A$ \\
\hline 13 & 201 & $\begin{array}{l}\text { 5'-TGTGCTTGACCATGCTCTTC-3' } \\
\text { 5'-AGTTGATGTCGCGCTGTATG-3' }\end{array}$ & $f(n b B$ \\
\hline
\end{tabular}

\section{RESULTS}

All bacterial isolates (22 isolates) were identified as $S$. aureus after standard biochemical testing and PCR (Figure 1). The most frequent gene was can, which was detected in six S. aureus isolates $(27.27 \%)$ (Figure 2).

Figure 1- Detection of 275 bp band in electrophoresis of the PCR products. No.1: Ladder (100 bp), No.2: negative control, No.3: positive control. No.4-14: S. aureus isolates.

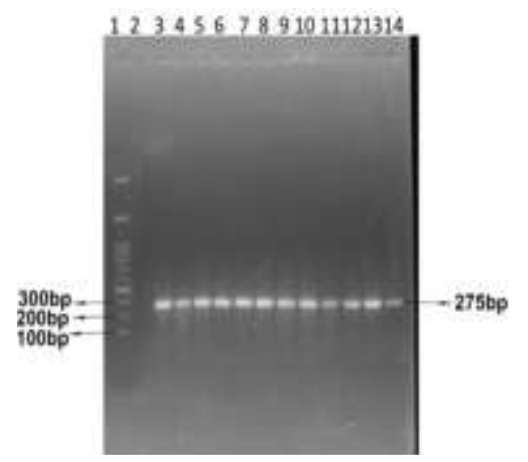

Figure 3- Detection of 192 bp bands in electrophoresis of the PCR products. No.1: Ladder (100 bp), No.2: negative control, No.3: positive control, No.4: fnbB-positive isolate

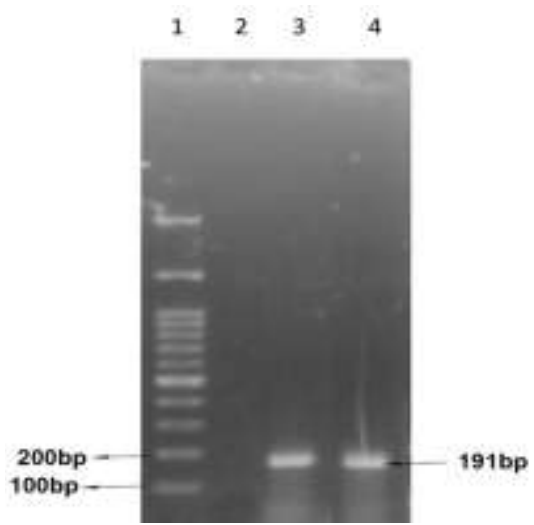

Among the $S$. aureus isolates tested, only one isolate $(4.54 \%)$ was positive for the $f n b A$ gene. In addition, only one isolate $(4.54 \%)$ was positive for the $f n b A$ gene. None of the isolates contained more than one gene.

Figure 2- Detection of 192 bp band in electrophoresis of the PCR products. No.1: Ladder (100 bp), No.2: negative control, No.3: nositive control. No. 4-9: can-nositive isolates.

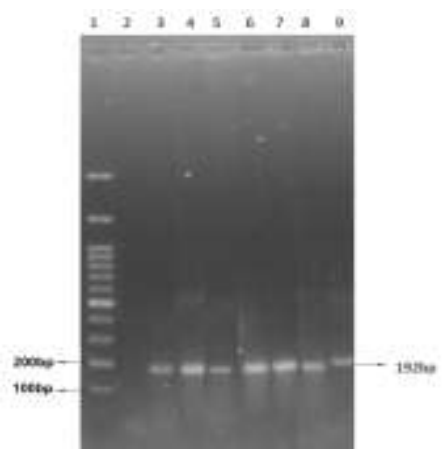

Figure 4-Detection of 201 bp bands in electrophoresis of the PCR products. No.1: Ladder (100 bp), No.2: negative control, No.3: positive control, No.4: fnbB-positive isolate

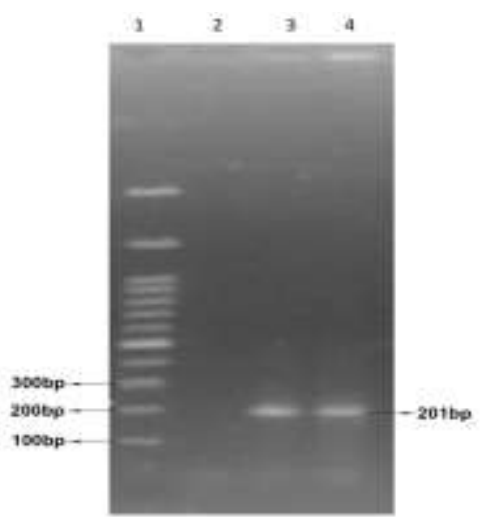




\section{DISCUSSION}

A wide range of pathogenic microorganisms on surfaces or in contact with food products could act as sources of infections. S. aureus is an important pathogen that can multiply in milk and dairy products, and cause infection in humans. On the other hand, it can cause chronic mastitis through biofilm formation (16), or cause resistance against antibiotics (17). S. aureus is also known for production of slime layer. Bacteria that are not able to produce slime layer, form a weaker biofilm (18). Evidence suggests that proteins including Cna and fnbpA, fnbpB are essential for adhesion and virulence of bacteria (7, 19). In this study, cna was the most prevalent gene in the $S$. aureus isolates tested, which is inconsistent with other studies suggesting that the cna gene has low abundance in isolates of human origin (21) and livestock (22). Further studies with larger sample size could help clarify the prevalence of the cna gene in S. aureus isolates from dairy products. The role of $\mathrm{Cna}$ has been well demonstrated in virulence and development of diseases such as septic arthritis and bone infections (23). In study of Dastmalchi Saei et al., 43 of $45 \mathrm{~S}$. aureus isolates from sheep with mastitis contained the cna gene (24), which is inconsistent with our results. Thomas et al. analyzed 159 isolates from different regions and reported the prevalence of the cna gene as $67 \%$ and $44 \%$ in the UK and New Zealand, respectively (25). It is established that FnbpA and FnbpB play a crucial role in the assembly,

\section{REFERENCES}

1. Kumar CG, Anand SK. Significance of microbial biofilms in food industry: a review. Int J Food Microbiol. 1998; 42(1-2): 9-27.

2. Wanasinghe DD. In vitro adherence of Staphylococcus aureus to bovine mammary gland epithelial cells. Acta Vet Scand. 1981; 22: 99-108. PMID: 7258035.

3. Gudding R, McDonald JS, Cheville NF. Pathogenesis of Staphylococcus aureus mastitis: bacteriologic, histologic, and ultrastructural pathologic findings. Am J Vet Res. 1984; 45: 2525-31.

4. Foster TJ, Hook M. Surface protein adhesins of Staphylococcus aureus. Trends Microbiol. 1998; 6(12): 484-8. PMID:10036727.

5. Hauck CR, Ohlsen K. Sticky connections: extracellular matrix protein recognition and integrin-mediated cellular invasion by Staphylococcus aureus. Curr Opin Microbiol. 2006; 9(1): 5-11. adhesion and invasion of $S$. aureus to study, only one isolate $(4.54 \%)$ contained the $f n b A$ or $f n b B$ gene. In a similar study, $86.66 \%$ and $77.77 \%$ of the isolates contained the $f n b A$ and $f n b B$ genes, respectively (24), which is inconsistent with our results. We also found that none of the isolates contained more than one gene. In study of Duran et al. on S. aureus isolates from ulcers, $78.4 \%$ of the isolates contained the cna gene, while $97.7 \%$ of the isolates contained the fnbA gene (28). Considering the low frequency of the genes tested and their co-presence, it can be concluded that such isolates have weaker ability to attach to mammary cells, and lower dominance and emissions than other isolates. In addition, study of Hesen et al. reported the difference in adhesion and invasion ability among $S$. aureus isolates (29).

\section{CONCLUSION}

Majority of the isolates tested in our study were negative for presence of the can, fnbA and $f n b B$ genes. Therefore, it can be concluded that these isolates may have weak biofilmforming ability in traditional cheese.

\section{ACKNOWLEDGEMENTS}

We are grateful to Dr Asghar Tanumand for assisting us in performing DNA extraction and PCR assay.

\section{CONFLICT OF INTEREST}

The authors declare that there is no conflict of interest.

6. Jett $\mathrm{BD}$, Gilmore MS. Internalization of Staphylococcus aureus by human corneal epithelial cells: role of bacterial fibronectin binding protein and host cell factors. Infect Immun. 2002;70:4697-700. doi: 10.1128/IAI.70.8.4697-4700.2002.

7. Smeltzer MS, Gillaspy AF. Molecular pathogenesis of staphylococcal osteomyelitis. Poultry Sci. 2000; 79(7): 1042-49.

8. Cheung AL, Fischetti VA. The role of fibrinogen in mediating staphylococcal adherence to fibers. J Surg Res. 1991; 50(2): 150-5.

9. Patti JM, Bremell T, Krajewska-Pietrasik D, Abdelnour A, Tarkowski A, Ryden $\mathrm{C}$, et al. The Staphylococcus aureus collagen adhesin is a virulence determinant in experimental septic arthritis. Infect Immun. 1994; 62(1): 152-61. 
10. Lammers A, Nuijten PJ, Smith HE. The fibronectin binding proteins of Staphylococcus aureus are required for adhesion to and invasion of bovine mammary gland cells. Fems Microbiol Lett. 1999; 180(1): 103-9.

11. Atashpaz S, Khani S, Barzegari A, Barar J, Vahed SZ, Azarbaijani R, et al. A robust universal method for extraction of genomic DNA from bacterial species. Mikrobiologiia. 2010; 79(4): 562-6.

12. Brakstad OG, Aasbakk K, Maeland JA. Detection of Staphylococcus aureus by polymerase chain reaction amplification of the nuc gene. J Clin Microbiol. 1992; 30(7): 1654-60.

13. Arciola CR, Campoccia D, Gamberini S, Baldassarri L, Montanaro L. Prevalence of cna, fnbA and fnbB adhesin genes among Staphylococcus aureus isolates from orthopedic infections associated to different types of implant. Fems Microbiol Lett. 2005; 246(1): 81-6.

14. Montanaro L, Arciola CR, Baldassarri L, Borsetti E. Presence and expression of collagen adhesin gene (cna) and slime production in Staphylococcus aureus strains from orthopaedic prosthesis infections. Biomaterials. 1999; 20(20): 1945-49.

15. Montanaro L, Arciola CR, Borsetti E, Collamati S, Baldassarri L, Montanaro L. Detection of fibronectinbinding protein genes in staphylococcal strains from peri-prosthesis infections. New Microbiol. 1999; 22(4): 331-6.

16. Aarnisalo K, Lundén J, Korkeala H, Wirtanen G. Susceptibility of Listeria monocytogenes strains to disinfectants and chlorinated alkaline cleaners at cold temperatures. LWT - Food Science and Technology. 2007; 40(6): 1041-8.

17. Melo PdC, Ferreira LM, Nader Filho A, Zafalon LF, Vicente HIG, Souza VD. Comparison of methods for the detection of biofilm formation by Staphylococcus aureus isolated from bovine subclinical mastitis. Braz $\mathrm{J}$ Microbiol. 2013; 44(1): 119-24. doi: 10.1590/S151783822013005000031 .

18. Gotz F. Staphylococcus and biofilms. Mol Microbiol. 2002; 43(6): 1367-78.

19. Hudson MC, Ramp WK, Frankenburg KP. Staphylococcus aureus adhesion to bone matrix and bone-associated biomaterials. Fems Microbiol Lett. 1999; 173(2): 279-84.
20. Smeltzer MS, Gillaspy AF, Pratt FL, Thames MD, Iandolo JJ. Prevalence and chromosomal map location of Staphylococcus aureus adhesin genes. Gene. 1997; 196(1-1): 249-59.

21. Nashev D, Toshkova K, Salasia SI, Hassan AA, Lammler C, Zschock M. Distribution of virulence genes of Staphylococcus aureus isolated from stable nasal carriers. Fems Microbiol Lett. 2004; 233: 45-52. DOI:10.1016/j.femsle.2004.01.032.

22. Reinoso EB, El-Sayed A, Lammler C, Bogni C, Zschock M. Genotyping of Staphylococcus aureus isolated from humans, bovine subclinical mastitis and food samples in Argentina. Microbiol Res. 2008; 163(3): 314-22. DOI:10.1016/j.micres.2006.05.013.

23. Elasri MO, Thomas JR, Skinner RA, Blevins JS, Beenken KE, Nelson CL, et al. Staphylococcus aureus collagen adhesion contributes to the pathogenesis of osteomyelitis. Bone. 2002; 30(1): 275-80.

24. Dastmalchi saei H, Aghdasi S, Mohamad zadeh H. Frequency analysis of adhesin genes cna, fnbA and fnbB in Staphylococcus aureus isolates from sheep mastitis. Iran Vet J. 2013; 9(1): 19-29. [Persian]

25. Thomas MG, Peacock S, Daenke S, Berendt AR. Adhesion of Staphylococcus aureus to collagen is not a major virulence determinant for septic arthritis, osteomyelitis, or endocarditis. J Infect Dis. 1999; 179(1): 291-3.

26. Lammers A, Nuijten PJ, Kruijt E, StockhofeZurwieden N, Vecht U, Smith HE, et al. Cell tropism of Staphylococcus aureus in bovine mammary gland cell cultures. Vet Microbiol. 1999; 67(2): 77-89.

27. Dziewanowska K, Patti JM, Deobald CF, Bayles KW, Trumble WR, Bohach GA. Fibronectin binding protein and host cell tyrosine kinase are required for internalization of Staphylococcus aureus by epithelial cells. Infect Immun. 1999; 67(9): 4673-78.

28. Duran N, Dogramaci Y, Ozer B, Demir C, Kalaci A. Detection of adhesin genes and slime production among Staphylococci in orthopaedic surgical wounds. Afr J Microbiol Res. 2010; 4(9): 708-15.

29. Hensen SM, Pavicic MJ, Lohuis JA, Poutrel B. Use of bovine primary mammary epithelial cells for the comparison of adherence and invasion ability of Staphylococcus aureus strains. J Dairy Sci. 2000; 83(3): 418-29. 